\section{電気と技術の塊： 金属チタンの製造法}

on

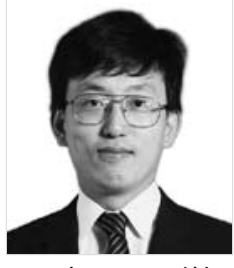

岡部徹

\section{1.はじめに}

一般には知られていないことであるが，日本は世界に冠 たるレアメタルの “生産大国・技術（超）大国”である。 資源を全量輸入し，人件費とエネルギーコストが高く，世 界で最も環境規制が厳しいなどの幾重ものハンデイを負い ながらも，現在，多くのレアメタルの生産技術では世界の トップを走り続けている。

今後，普及が期待される金属チタンについても，技術力 では世界をリードしており，高い電力コストをものともせ ず，今でも日本は世界生産量の約 3 割の金属チタンを製造 している。原料とエネルギーのすべてを輸入し, 高い労働 コストと環境コストを負担しながらも, “技術と電気の塊” であるチタンを全世界に輸出し続けていることは, 日本が 誇る高い技術力の証といえよう。

本稿では，プロセス技術が進歩すれば爆発的な成長が期 待される “夢の素材” チタンの製造プロセスとその特徵に ついて解説し，今後の展望について紹介する。

\section{2. 資源的には豊富なレアメタル：チタン}

レアメタル（Rare Metal）とは “特殊金属”や“稀少金 属”という意味で広く一般に受けとめられているが，資源 的には必ずしも“稀な”金属であるとは限らない。例え ば，本稿で紹介するチタン（Ti）は，レアメタルの代表格 であることはだれもが認めるものの, 地殼中に存在する元 素の量としては 9 番目に多い元素である。広く普及してい るべースメタル（Base Metal：主要金属）である銅 $(\mathrm{Cu})$ や鉛 $(\mathrm{Pb})$, 亜鉛 $(\mathrm{Zn})$ はもとより, ステンレス鋼の構成 元素であるニッケル $(\mathrm{Ni})$ やクロム $(\mathrm{Cr})$ と比べても, チタンは桁違いに埋蔵量が多い金属である。

賦存量が多く，次世代の構造材料として普及しつつある チタンが “レア”メタルと言われる主な理由は，この金属 が化学的に活性なため, 製鍊が難しく純度の高い金属を製 造するのが技術的に困難なためである。チタンは，軽くて 高強度なだけでなく，抜群の耐腐食性を有する金属の代表 格であるが,これは金属そのものが不活性なためではな

表 1 代表的な金属の物性と生産量 ${ }^{\mathrm{ab}}$, 価格

\begin{tabular}{|c|c|c|c|c|c|c|c|c|}
\hline \multicolumn{2}{|c|}{ 金属素材 } & $\begin{array}{l}\text { 融点 } \\
\left({ }^{\circ} \mathrm{C}\right)\end{array}$ & $\begin{array}{l}\text { 密度 } \\
(\mathrm{g} / \mathrm{cc})\end{array}$ & 比強度 ${ }^{\mathrm{c}}$ & $\begin{array}{l}\text { 世界生産量 }^{a} \\
\text { (t/年 } \cdot \text { 世界) }\end{array}$ & $\begin{array}{c}\text { 日本の生産量 }{ }^{a} \\
\text { (t/年 · 日本) }\end{array}$ & $\begin{array}{l}\text { 日本の生産 } \\
\text { シェア (\%) }\end{array}$ & $\begin{array}{c}\text { 価格（概数） } \\
(¥ / \mathrm{kg})\end{array}$ \\
\hline 鉄（粗鋼） & $\mathrm{Fe}-\mathrm{C}$ & 1,535 & 7.9 & $4 \sim 7$ & $1,130,000,000$ & $110,000,000$ & 10 & $50 \sim$ \\
\hline ステンレス鋼 ${ }^{d}$ & $\mathrm{Fe}-\mathrm{Cr}-\mathrm{Ni}$ & & $(7.9)$ & $6 \sim 10$ & $25,000,000$ & $4,000,000$ & 16 & $200 \sim$ \\
\hline アルミニウム & $\mathrm{Al}$ & 660 & 2.7 & $3 \sim 6$ & $32,000,000$ & 6,500 & 0 & $200 \sim 600$ \\
\hline 銅 & $\mathrm{Cu}$ & 1,083 & 8.9 & $(2 \sim 4)$ & $16,000,000$ & $1,400,000$ & 9 & $200 \sim 600$ \\
\hline 亜鉛 & $\mathrm{Zn}$ & 419 & 7.1 & & $10,000,000$ & 700,000 & 7 & $100 \sim 250$ \\
\hline 鉛 & $\mathrm{Pb}$ & 328 & 11.3 & $(0.15)$ & $6,800,000$ & 300,000 & 4 & $100 \sim 250$ \\
\hline マグネシウム b & $\mathrm{Mg}$ & 651 & 1.7 & $5 \sim 11$ & 640,000 & 0 & 0 & $200 \sim 300$ \\
\hline チタン ${ }^{b}$ & $\mathrm{Ti}$ & 1,668 & 4.5 & $6 \sim 13$ & 130,000 & 39,000 & 30 & $1,000 \sim 3,000$ \\
\hline
\end{tabular}

$\mathrm{a}$ ：主として，世界鉱物資源データブック (第 2 版) : 資源・素材学会資源経済部門委員会・東京大学生産技術研究所編, (才 一公社) (2006)

b : Annual Review 2006（素材編）：工業レアメタル（アルム出版社），vol. 122 (2006）

$\mathrm{c}$ : 単位体積あたりの強度 $\left(\left(\mathrm{kgf} / \mathrm{mm}^{2}\right) /(\mathrm{g} / \mathrm{cc})\right)$

$\mathrm{d}$ ：代表的なステンレス鋼である SUS304（18\% Cr-8\% Ni）は $400 ¥ / \mathrm{kg}$ 程度

おかべ・とおる 1993 年 京都大学大学院博士課程修了（工 博)。1993 年〜1995 年 マサチューセッツ工科大学博士研究 員。1995 年 2000 年 東北大学素材工学研究所助手。2001 年 東京大学生産技術研究所助教授 (現職)。
い。ステンレス鋼と同様，金属表面に形成される酸化物が 緻密で化学的に不活性なためである。

表 1 には，チタンだけでなく，鉄（Fe）やアルミニウ ム (Al) などの主要金属の主な物性, 生産量, 価格の概数 
などを列記した ${ }^{(1)}{ }^{(2)}$ 。表から分かるように，チタンは，鉄 やアルミニウムなどのベースメタルに比べ，現状では，生 産量が桁違いに小さいことが分かる。表には，銅や鉛，亜 鉛など，チタンより資源量がはるかに少ない金属の諸量も 参考までに示すが，これらの金属と比べても，チ夕ンの生 産量は小さく, 生産量や価格という観点からは, 現状では レアメタルの範疇に入る。

\section{3. チタンの製造プロセスの原理と特徵}

チタンは，資源的にはルチル鉱石 $\left(\mathrm{TiO}_{2}\right)$ やイルメナ イト鉱石 $\left(\mathrm{FeTiO}_{\mathrm{x}}\right)$ などの化学的に極めて安定な酸化物 の形で存在する。先に述べたように地球上に広く豊富に存 在するため，元素としてのチタンの発見は古く，今から 200 年以上も昔であった。

通常，元素の存在が明らかになれば，化学者たちは新元 素を単離し，物性を測定して元素の特性に応じて利用する のが一般的である。しかし，チタンの酸化物を還元して (酸素を取り除き) 高純度の金属を得るのが難しく，圧延 ができる高純度の金属が得られるまでには元素の発見から 120 年もの歳月を要した。

チタンは他の金属元素とは異なり特異的に酸素との親和 力が強く，そのうえ酸素が金属中に固溶すると物性が大き く変化する。このため，1910 年になって初めて高純度の 金属チタンの製造方法が開発されるまでは，その融点すら も不明の “未知の金属”であった。

チタンが量産金属として工業的に製造されるようになっ たのは，今から約 60 年前の 1945 年のことである。マグネ シウム $(\mathrm{Mg})$ やシリコン $(\mathrm{Si})$ と同様，量産金属の中で は比較的新しい元素の 1 つであり, 今もなお高純度の金属 を効率良く製造するプロセスは確立されていない。現在の チタンの量産プロセスは，技術的には発展途上であり，イ ノベーションが必要であると考えられる。

クロール法によるチタン製錬反応

塩化工程

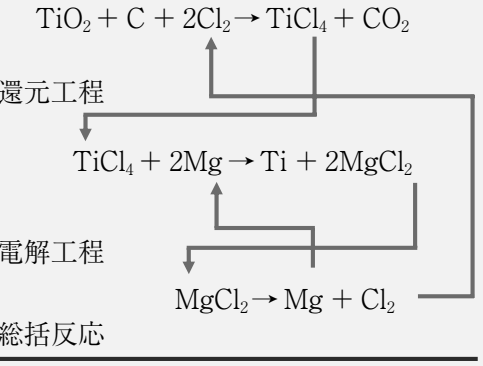

$\mathrm{TiO}_{2}+\mathrm{C} \rightarrow \mathrm{Ti}+\mathrm{CO}_{2}$

$\left(\mathrm{TiCl}_{4}, \mathrm{Mg}, \mathrm{MgCl}_{2}, \cdots\right)$

図 1 チタンの製造プロセスの反応図
現在チタンは，工業的には図 1 に示すクロール法とよば れる方法により製造されている(3) (4)。この方法では，まず 酸化物の鉱石を塩素 $\left(\mathrm{Cl}_{2}\right)$ と反応させて, 塩化物 $\left(\mathrm{TiCl}_{4}\right)$ の中間原料を製造し，これを蒸留精製して酸素や鉄などの 不純物を取り除く。次に得られた高純度の $\mathrm{TiCl}_{4}$ は, 図 2 に示す反応装置の中で金属マグネシウムを還元剤として用 いて還元し，スポンジ状の固体の金属チタンを製造す る(5)。こうして得られた金属チタンは, 反応生成物である 液体の $\mathrm{MgCl}_{2}$ を高温で分離後に冷却し，破砕・溶解・圧 延して板やパイプなどに加工される。

クロール法は，酸素濃度が低く純度が高い金属チタンが 確実に得られる優れた製造法であり, 反応生成物 $\left(\mathrm{MgCl}_{2}\right)$ も完全に再利用できる点でも優れた方法である。しかし， $800 \sim 1,000^{\circ} \mathrm{C}$ の高温で四塩化チタン $\left(\mathrm{TiCl}_{4}\right)$ と還元剂の マグネシウムが反応するプロセスは，膨大な発熱を伴うた め温度制御が難しく，反応速度を大幅に増大することがで きないという欠点がある。チタンの還元プロセスでは，発 生する熱をいかにして効率良く取り除くかが解決すべき重 要な技術課題である。

現在，最新鋭の大型の反応装置を用いて一度に $10 \mathrm{t} の$ チタンを製造できるようになったが(6)，この場合でも，反 応熱の制御が難しく，還元・分離工程だけで約 2 週間もか かる。現状では，チタンは量産金属の中では極めて生産性 が低いプロセスで製造されていることが分かる。

\section{4. マグネシウムの再生電解：電気の塊のチタン}

還元プロセスにおける反応熱は，還元剤である金属マグ

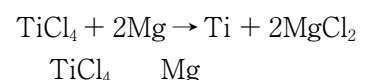

$\mathrm{TiCl}_{4} \quad \mathrm{Mg}$

(原料) (還元剂)

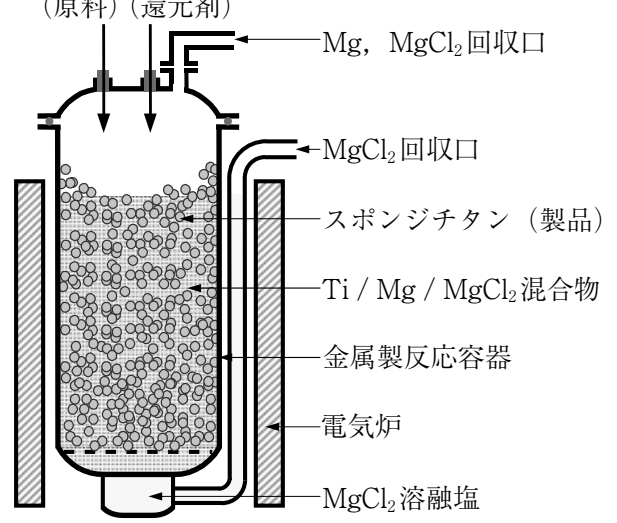

高純度のチタンが製造できる

塩素とマグネシウムの循環利用が行われている

$\triangle$ 労働力を要するパッチ式の生産方式（生産性が低い）

$\times$ 莫大な反応熱を効率良く取り除くことができない

$\times$ 生産速度が低く, 高々 $1 \mathrm{t} /$ day 程度である

図 2 チタンの還元装置の模式図（クロール法） 
ネシウムが酸化して, $\mathrm{MgCl}_{2}$ に変化するときに発生する熱 であり，チタンの還元工程ではほとんど電力を消費しな い。しかし, この反応熱の源は電力である。なぜなら, 図 1 に示すようにチタンの還元プロセスで生成する $\mathrm{MgCl}_{2}$ は，溶融塩電解法により電気分解によって再び金属マグネ シウム $(\mathrm{Mg})$ と塩素 $\left(\mathrm{Cl}_{2}\right)$ ガスに再生し, 循環利用して いるからである。

クロール法で，チタンを $1 \mathrm{t}$ 製造するのに約 $1 \mathrm{t}$ の還元 凨の金属マグネシウムが必要である。このマグネシウムは チタンの還元工程の反応生成物である高純度の無水 $\mathrm{MgCl}_{2}$ を電解して再生している。現在のチタンの生産規模は年間 13 万tであるため, チタン製鍊工場において毎年 13 万 $\mathrm{t}$

（a）シングルセル電解法

陰極 $: \mathrm{Mg}^{2+}($ 溶融塩 $)+2 \mathrm{e}^{-} \rightarrow \mathrm{Mg}$ (液体 $)$

陽極： $2 \mathrm{Cl}^{-}$(溶融塩 $) \quad \rightarrow \mathrm{Cl}_{2}$ (気体 $)+2 \mathrm{e}$

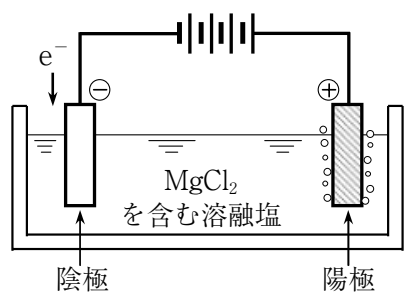

（b）バイポーラ電極式マルチセル電解法 (福極式電解法，マルチポーラ電解法）

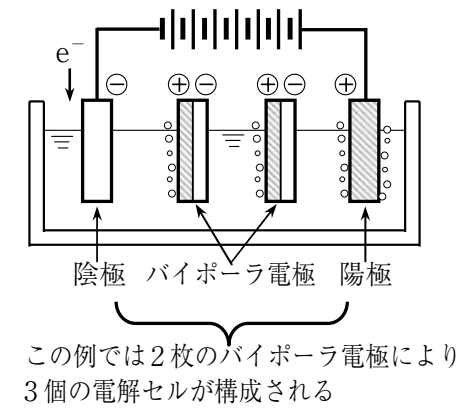

図 3 クロール法における反応生成物の $\mathrm{MgCl}_{2}$ の再生 電解に応用されている溶融塩電解法 (表 2 参照)
規模の金属マグネシウムが電解により生産されていること になる。ほとんどの場合，チタン工場内のマグネシウムは 凝固することも無く，すぐに還元剤として消費されて膨大 な反応熱とともに $\mathrm{MgCl}_{2}$ に変化し，見えないところで循 環している。

図 3(a)に, 無水 $\mathrm{MgCl}_{2}$ の溶融塩電解法の原理図を示 す。 $\mathrm{MgCl}_{2}$ を約 20 mass \% 含む $\mathrm{NaCl}-\mathrm{CaCl}_{2}$ 系溶融塩を約 $670^{\circ} \mathrm{C}$ で電気分解すると，陰極には液体のマグネシウム が，陽極には塩素ガスが生成する。液体マグネシウムの密 度は溶融塩より小さいため, 溶融塩中の電極表面に生成し たマグネシウムは浮上する。溶融塩中を浮上する液体マグ ネシウムと塩素ガスの分離は, 電極の構造や溶融塩の流れ をうまく利用して行う必要がある。このため，実際の電解 セルの構造は複雑で, 液体マグネシウムと塩素ガスの再結 合による電解効率の低下を防ぐ工夫がなされている。

図 3(a) に示す電解セル（シングルセル）を用いてマグ ネシウムの生産速度を向上させるためには，同一の電解セ ルを複数個直列につなげるか，あるいは電解電流を増大さ せる方法がある。しかし，これらの場合は，電解に伴う発 熱（ジュール熱）も増大するためエネルギー的な利得は少 ない。

図 3(b) には，バイポーラ電極式マルチセル電解法（バ イポーラ電解法, 複極式電解法）によるマグネシウム電解 の模式図を示す。陽極と院極の間に炭素のバイポーラ電極 （複極）を挿入すると，溶融塩電解槽を複数の電解セルに 分割することが原理的には可能であり，一定電流条件下で もマグネシウムの生成量を増大させることができる。

実際の工業電解では，漏れ電流や生成物の再結合（再酸 化）などによる電解効率の低下が起こるが，図 3(b)に示 すバイポーラ電解セルは, 図 $3(\mathrm{a})$ に示すシングルセル電 解槽に比べ，原理的には同一電流条件下では約 3 倍の生産 性がある。このようにバイポーラ電解が利用できる場合

表 2 無水 $\mathrm{MgCl}_{2}$ の再生電解におけるシングル型とバイポーラ型の電解セルの操業パラメータ比較（図 3 参照）

\begin{tabular}{|c|c|c|c|c|c|c|c|}
\hline \multirow{2}{*}{\multicolumn{2}{|c|}{ パラメータ }} & \multicolumn{3}{|c|}{ シングルセル電解法 } & \multicolumn{3}{|c|}{ バイポーラ電解法 } \\
\hline & & S 社 & $\mathrm{S}$ 社 & $\mathrm{T}$ 社 & S 社 & $\mathrm{T}$ 社 & S 社 \\
\hline 電解セル容量 & 量と構造 & $40 \mathrm{kA}$-単極 & $80 \mathrm{kA}$-単極 & $100 \mathrm{kA}$-単極 & $110 \mathrm{kA}-3$ 極 & $120 \mathrm{kA}-3$ 極 & $110 \mathrm{kA}-5$ 極 \\
\hline 槽電流 & $(\mathrm{kA})$ & 40 & 80 & $95 \sim 100$ & $110 \times 3$ & $(70 \sim 120) \times 3$ & $110 \times 5$ \\
\hline 槽電圧 & (V) & 7.3 & 5.7 & $4.7 \sim 5.2$ & 10.5 & $10 \sim 11$ & 17 \\
\hline 電流密度 & $\left(\mathrm{A} / \mathrm{cm}^{2}\right)$ & 1.2 & 0.8 & & 0.55 & & 0.60 \\
\hline 操業温度 & $\left({ }^{\circ} \mathrm{C}\right)$ & $675 \sim 685$ & $660 \sim 670$ & $680 \sim 700$ & 652 & $665 \sim 670$ & 654 \\
\hline 電流効率 & (\%) & 90 & 93 & $80 \sim 90$ & $75 \sim 80$ & $75 \sim 80$ & $70 \sim 75$ \\
\hline エネルギー効率*1 & (\%) & 32 & 41 & $40 \sim 50$ & $55 \sim 59$ & $56 \sim 58$ & $53 \sim 57$ \\
\hline 電力原単位 & $(\mathrm{kWh} / \mathrm{kg})$ & 17.5 & 13.9 & 14 & 9.8 & $9 \sim 11$ & 10 \\
\hline 生産性 & $(\mathrm{t} /$ year $\cdot$ cell $)$ & $\sim 140$ & $\sim 290$ & $\sim 350$ & $\sim 1000$ & $\sim 1000$ & $\sim 1,600$ \\
\hline
\end{tabular}

$* 1:$ バイポーラ電解は内熱式反応であるが，エネルギー効率は理論分解電圧 $E_{\mathrm{r}}$ を用いて計算した。 $933 \mathrm{~K}\left(660^{\circ} \mathrm{C}\right)$ に打ける理論分解電圧 : $E_{\mathrm{r}}(=\Delta G / \mathrm{n} F)=2.54 \mathrm{~V}$, 理論稼動電圧 $: E_{\mathrm{d}}\left(=\Delta H^{\circ} / \mathrm{n} F\right)=3.10 \mathrm{~V}$ 電解浴代表組成（S 社）: $\mathrm{MgCl}_{2}: 18 \sim 23 \%, \mathrm{NaCl}: 55 \sim 58 \%, \mathrm{CaCl}_{2}: 20 \sim 25 \%, \mathrm{MgF}_{2}: 2 \%$ (mass\%) 電解浴代表組成（T 社）： $\mathrm{MgCl}_{2}$ : 20\%, $\mathrm{NaCl}: \sim 48 \%, \mathrm{CaCl}_{2}: \sim 28 \%, \mathrm{KCl} ： \sim 2 \%, \mathrm{MgF}_{2}: \sim 2 \%$ (mass\%) 
は，電解による熱的なロスを低減することが可能となり， また空間利用効率を大幅に増大できるため, 少ない量の溶 融塩で生産性を向上できる利点がある。

表 2 に示すように，現在，工業的には 70〜 $120 \mathrm{kA}$ ，七 ル電圧 $10 \sim 11 \mathrm{~V}$ の 3 極のバイポーラセルがチタン製錬工 場において複数稼動しており，10 kWh/ $\mathrm{kgMg}$ 程度の電力 原単位でマグネシウムの再生電解が行われている ${ }^{(5)(7) \sim(9)}$ 。

\section{5. 金属製鍊の電力原単位}

マグネシウムの再生電解の電力原単位は, シングルセル 電解を行っていた 25 年前に比べ約半分となったが，これ は前述のバイポーラ電解技術の進展によるところが大き い。表 2 に示すエネルギー効率等の解析については文献を 参考にされたいが(11)，工業電解においてエネルギー効率 が50\%を超えている点は驚異的なことであり，電解製錬 の発展の歴史の中で特筆すべき点である。

高い電力コストにもかかわらず, 今も日本が莫大な電力 を消費するチタンの生産大国であり続けている大きな理由 の一つとして, 本稿で紹介した溶融塩電解を初めとするプ ロセス技術に関する高い技術力が挙げられる。

表 3 には，チタンを初めとする金属の製造にかかわる電 力原単位を示す。アルミニウムは “電気の缶詰” と言われ るが，チタンはこれよりもはるかに大きな“電気の塊”で あることが分かる。

前章ではチタン製錬（クロール法）における $\mathrm{MgCl}_{2}$ の 再生電解について紹介したが，この手法は，一般的な金属 マグネシウムの製造方法とは大きく異なる点に注意された い。近年，用途が拡大しているマグネシウムやその合金 は，金属熱還元法と溶融塩電解法の二つの異なる手法によ り生産されている ${ }^{(8)}(10)$ 。一般に利用される金属マグネシ ウムを電解法により製造する場合は, クロール法で得られ る高純度の無水 $\mathrm{MgCl}_{2}$ 原料の場合とは異なり, 原料中の 不純物が電極と反応して電極が消耗され形状が変化する。 このため, 一般のマグネシウム電解では，前章で紹介した
効率の良いバイポーラ電解法が利用できず，表 3 に示すよ うにマグネシウム生産のエネルギー効率が $30 \%$ 程度まで 低くなる。量産されているマグネシウム $1 \mathrm{t}$ あたり電力原 単位は，チタン製造の電力原単位とさほど変わらないこと も興味深い。

\section{6. 今後の展望}

本稿では，チタンの現状や製造プロセスについて簡単に 解説した。チタンは，レアメタルの中では資源が豊富な “活性金属”として分類され，高品質のものを効率良く作 るのが困難で，製造には極めて高い技術と莫大なエネルギ 一を要する特殊金属の代表格である。

チタンの生産量が年間 10 万 $\mathrm{t} レ$ ベルである限り，現行 の生産法（クロール法 $+\mathrm{MgCl}_{2}$ の再生電解）は完成度の 高い生産技術として存続するであろう。しかし，チタンが アルミニウムのようにコモンメタルに変身し，より豊かな 社会に多大な貢献をもたらす新素材として発展するために は，プロセス原理から再検討し革新的な製造技術を開発す る必要がある。

最近は, 航空機や化学プラントの需要の増加や用途の拡 大に伴い，チタンの需要が急増しているが，現在の方法と 設備容量では生産が追いつかない。このため，新しい夕イ プの溶融塩電解法により酸化物から直接金属チタンを製造 する方法など，新しい製造プロセスの研究開発が国内外で 精力的に行われている。チタンの新しい製錬法の開発動向 については解説を参照されたいが(12)〜(15)，いずれにしても， チタンの製造には莫大な電力を要することは変わらない。

日本は，チタンのプロセス技術に関しては，これからも 世界をリードし続けることが期待されるが，昨今の世界的 な資源やエネルギー事情を考えると明るい将来が確約され ているとは言い難い。今後も日本がチタンの生産大国・技 術超大国として君臨し続けるためには，新規なプロセス技 術を世界に先んじて開発し続ける必要がある。

将来的には，レアメタルの代表であるチタンが技術革新

表 3 チタン製錬などの電力原単位（推定值）

\begin{tabular}{|c|c|c|c|c|c|}
\hline \multicolumn{2}{|l|}{ 金属素材 } & $\begin{array}{l}\text { 密度 } \\
(\mathrm{g} / \mathrm{cc})\end{array}$ & $\begin{array}{l}\text { 電力原単位 } \\
(\mathrm{MWh} / \mathrm{t})\end{array}$ & $\begin{array}{c}\text { 単位体積あたりの } \\
\text { 電力原単位 } \\
(\mathrm{kWh} / 1,000 \mathrm{cc} \text { Metal })\end{array}$ & 備考 \\
\hline $\begin{array}{l}\text { チタン } \\
\text { (クロール法) }\end{array}$ & $\mathrm{Ti}$ & 4.5 & 17 & 77 & $\begin{array}{l}\text { 内 } \mathrm{Mg} \text { 再生電解などに } 12 \mathrm{MWh} / \mathrm{t} \\
1982 \text { 年は, } 23 \mathrm{MWh} / \mathrm{t} \mathrm{Ti}\end{array}$ \\
\hline $\begin{array}{l}\text { アルミニウム } \\
\text { (ホール・エル法) }\end{array}$ & $\mathrm{Al}$ & 2.7 & 13 & 35 & $\begin{array}{l}\text { セル電圧 : } 4.2 \mathrm{~V}, \text { 電流効率：約 } 95 \% \\
\text { エネルギー効率 : } 26 \%\end{array}$ \\
\hline $\begin{array}{l}\text { マグネシウム } \\
\text { (ダウ法) }\end{array}$ & $\mathrm{Mg}$ & 1.7 & 17 & 29 & $\begin{array}{l}\text { セル電圧 : } 6 \mathrm{~V}, \text { 電流効率：約 80\% } \\
\text { エネルギー効率 : } 33 \%\end{array}$ \\
\hline 鉄鋼 & $\mathrm{Fe}-\mathrm{C}$ & 7.9 & $(0.6)$ & (4) & $\begin{array}{l}\text { 還元に電力は使用せず。 } \\
\text { 括弧内は, 圧延等の加工を含む電力使用量 }\end{array}$ \\
\hline
\end{tabular}

$\mathrm{a}$ ：ここでは電解法のデー夕を載せたが，多くの Mg は電解法ではなく金属熱還元法により製造されている 最近は，14 MWh/ton の電力原単位（ダウ法）で生産できるところもある。 
により “夢の素材”から脱却し，アルミニウムやステンレ ス鋼と肩を並べる“コモンメタル”として成長し，より豊 かな社会に多大な貢献をもたらす新素材として一層普及す ることを切に期待している。

謝辞 : 本稿の内容に対して貴重な助言をいただいた東邦 チタニウム株式会社チタン技術部の小瀬村 晋氏と小野 有一 氏，東京電力株式会社技術開発本部の荻 宏美氏に記して 感謝します。

(平成 18 年 9 月 11 日受付)

\section{文 献}

（1）世界釷物資源データブック（第２版）：資源・素材学会資源経済 部門委員会・東京大学生産技術研究所編, オーム社（2006

(2) Annual Review 2006 (素材編)：工業レアメタル,アルム出版社, vol. 122 (2006)

( 3 ) W. Kroll: "The Production of Ductile Titanium", Tr. Electrochem. Soc., 78, pp. 35-47 (1940)
（4）岡部徹：「レアメタルの製造プロセス」, OHM，オーム社, vol. 93, no. 4 , pp. 37-41 (2006)

（5）友成忠雄：「チタニウム工業とその展望」,日本チタニウム協会, 全 636 頁 (2000)

（6）守屋惇郎・金井章：「住友シッチクス(株)のチタンの製造」,資源 と素材, vol. 109, no. 12, pp. 1164-1169 (1993)

（7）福山尚志・小泉昌明・花木道夫・小瀬村晋：「東邦チタニウム （株）のスポンジチタンとインゴットの製造」,資源と素材, vol. 109, no. 12, pp. 1157-1163 (1993)

（8）ママグネシウム技術便覧，日本マグネシウム協会編，カロス出版 （2000）（マグネシウム便覽,軽金属協会編（1975）絶版）

（9）小瀬村晋：第9回耐熱強勒チ夕ン研究部会資料, 日本鉄鋼協会 (平 成 4 年 4 月 24 日), (1992)

（10）伊藤靖彦編：溶融塩の科学と応用一エネルギー・環境技術への 展開アアイ・ピー・シー (2003)

（11）高橋正雄・増子昇:「工業電解の化学」, 株式会社アグネ (1979)

(12) 岡部徹・二上愛・小野勝敏：「解説：チタン製鍊プロセスの最近 の話題」,ふえらむ（日本鉄鋼協会会報）, vol. 7, no. 1, pp.39-45 (2001)

（13）鈴木亮輔：「解説：世界に扔けるチタンの新精錬法」,チタン, vol. 52, pp. 281-287 (2004)

（14）岡部徹：「解説：チタンの新製錬法」, 軽金属学会会誌, vol. 56, no, 11, pp. 537-543 (2005)

（15） 小笠原忠司：「日本のチタン製錬技術の進歩と将来展望」,チタン vol. 53, no. 2, pp. 103-108（2005） 